\title{
Sekuestrasi Karbon Beberapa Jenis Vegetasi Sebagai Basis Pengembangan Hutan Kota Jambi
}

\author{
Endriani* dan Sunarti \\ Jurusan Agroekoteknolgi Fakultas Pertanian Universitas Jambi
}

Email: eend_200662@yahoo.co.id

\begin{abstract}
ABSTRAK
Ketersediaan ruang terbuka hijau (RTH) di perkotaan sangat penting untuk menanggulangi dampak pemanasan global yang menjadi isu penting saat ini, terutama dalam menurunkan kadar gas CO2 sebagai hasil pembakaran bahan bakar fosil dari kenderaan bermotor dan asap pabrik.Tujuan penelitian untukmengevaluasi sekuestrasi karbon beberapa jenis vegetasi di hutan kota berbasis vegetasi; dan menyeleksi jenis pohon lokal Indonesia ekosistem dataran rendah kering yang berpotensi tinggi dalam sekuestrasi karbon dan memproduksi O2.Penelitian lapangan dilaksanakan pada Hutan Kota Muhammad Sabki Jambi, sedangkan analisis tanah dilakukan di Laboratorium Fisika dan Mineralogi Tanah dan Laboratorium Kimia dan Kesuburan Tanah Fakultas Pertania UNJA. Penelitian dilaksanakan selama enam bulan, dari Mei hingga Oktober 2019. Penelitian dilaksanakan dengan metode Survay, dan penempatan plot percobaan dilakukan dengan metode Purposive Sampling. Pengambilan data vegetasi dan biomassa, serta tanah pada masing-masing lokasi dibuat plot berukuran $10 \times 10$ m sebanyak 3 plot untuk pohon dan $5 \times 5$ m untuk sapling sebanyak 20 plot, sehingga terdapat 60 plot pada semua lokasi penelitian

Hasil penelitian menunjukkan bahwa Hutan Kota M Sabki memiliki sifat fisik tanah bervariasi menurut areapemanfaatan lahan, di antaranya terdapat variasi terhadap bobot volume tanah, dan porositas tanah. Area pemanfaatan rendah memiliki kerapatan pohon lebih tinggi dibandingkan zona pemanfaatan sedang dan pemanfaatan intensif. Hutan kota M Sabki pada area pemanfaatan rendah memiliki biomassa atas permukaan sebesar350,60 ton/ha, stok karbon 164,78 ton/ha, sekuestrasi CO2 sebesar 604,20 ton/ha dan mampu memproduksi O2 sebesar 441,06 ton/ha. Biomassa pada area pemanfaatan sedang sebesar 305,72 ton/ha, stok karbon sebesar 143,69, sekuestrasi CO2 sebesar 526,86, serta mampu memproduksi O2 sebesar 384,561 ton/ha. Biomasapada area pemanfaatan intensif sebesar 225,66 ton/ha, stok karbon sebesar 106,06, sekuestrasi CO2 sebesar 389.24, serta mampu memproduksi O2 sebesar 284,15 ton/ha.
\end{abstract}

Kata Kunci : biomasa pohon; fungsi hidrologi; sekuestrasi karbon,hutan kota

\section{PENDHULUAN}

Lebih dari setengah penduduk dunia sekarang tinggal di daerah perkotaan, dan angka ini terus meningkat denganlaju 4\% pada satu dekade tahun 2050. Sejak tahun 2007 jumlah penduduk kota di dunia lebih banyak dibandingkan jumlah penduduk desa, hingga tahun 2014 ini (UN, 2015). Indonesia, hasil sensus penduduk terakhir pada tahun 2010 menunjukkan bahwa proporsi jumlah penduduk kota sebesar $49,7 \%$, mengalami peningkatan sebesar 27,3\% dibandingkan dengan hasil sensus penduduk tiga puluh tahun sebelumnya (tahun 1980). Secara berurutan proporsi penduduk kota di Indonesia pada tahun 1980, 1990 dan 2000 adalah 22,4\%, 31,10\% dan 41,9\%. Ekpektasinya jumlah penduduk kota akan mencapai 69,2\% pada tahun 2030 (Puslit Kependudukan LIPI (2018).

Urbanisasi yang cepat menimbulkan tantangan sosial dan lingkungan yang besar seperti kesehatan manusia yang terancam (Gong et al., 2012), perubahan iklim lokal dan regional (Chrysanthou et al., 2014; Zhou et al., 2014), hilangnya habitat alami dan 
keanekaragaman hayati (Seto et al., 2012) dan degradasi kualitas air dan udara (Young et al., 2012).Undang-Undang Republik Indonesia No. 26 tahun 2007 tentang Perencanaan Tata Ruang. Ini mengharuskan setiap kota menyediakan dan memanfaatkan ruang hijau perkotaan minimal 30\% dari total area.Ruang Terbuka Hijau (RTH), adalah area memanjang atau mengelompok, yang penggunaannya lebih bersifat terbuka, tempat tumbuh tanaman, baik yang tumbuh tanaman secara alamiah maupun yang sengaja ditanam (KLH, 2010).

Sudah sejak lama dan diyakini secara luas bahwa area (petakan) hutan di daerah perkotaan memberikan banyak manfaat ekologis dan sosial, yang sebagian untuk mitigasi kerusakan lingkungan akibat urbanisasi (Nowak et al., 2013, 2014).Kota bertanggung jawab atas sekitar 75\% emisi karbon dioksida antropogenik global (CO2) (Seto et al., 2014). Dalam beberapa dekade terakhir, ada banyak penelitian yang dilakukan untuk mengukur penyerapan C hutan kota(Zhao et al., 2013; Raciti et al., 2014).

Davies et al. (2011) menemukan bahwa sejumlah besar karbon disimpan di dalam vegetasi di atas permukaan tanah di Leicester, Inggris, dan pohon-pohon menyumbang lebih dari $95 \%$ dari sumber karbon ini. Di beberapa daerah, terutama daerah kering, hutan kota dapat menyimpan lebih banyak karbon daripada daerah pinggiran kota dan pedesaan yang berdekatan, sebagai akibat dari penanaman pohon dan pengelolaan ruang hijau perkotaan (McHale et al., 2009). Beberapa penelitian juga menunjukkan bahwa kepadatan karbon vegetasi dan tingkat akumulasi karbon di hutan kota bisa lebih besar daripada hutan alam yang berdekatan (Davies et al., 2011; Hutyra et al., 2011).Andriono et al., (2013) tentang Ruang Terbuka hijau di kota Malang menunjukkan serapan karbon di RTH di kota Malang sebesar 158. 620,98 ton/ha pada tahun 2010 dan diprediksi menurun pada tahun-tahun berikutnya.

Jambi merupakan kota yang sedang berkembang baik dari segi populasi, pembangunan, perkantoran dan pertokoan (BPS, 2018). Tersedianya RTH di kota Jambi mutlak diperlukan sekarang maupun dimasa yang akan datang. Berdasarkan informasi Dinas Lingkungan Hidup Kota Jambi, secara keseluruhan terdapat delapan RTH di Kota Jambi dengan luas total 266,19 ha, salah satunya yaitu RTH hutan Kota Muhammad Sabki.

Keseimbangan $\mathrm{C}$ setelah aforestasi sangat dipengaruhi oleh jenis pohon (PerezCruzado et al., 2011), sebagai hasil perbedaan pada laju pertumbuhan pohon. Produksi dan kualitas serasah yang dipengaruhi oleh jenis pohon mempunyai pengaruh yang kuat terhadap dinamika SOC (Berg et al., 2009; Vesterdal et al., 2008). Perbedaan dalam dinamika SOC dipengaruhi oleh perbedaan laju pergantian akar (Vesterdal et al, 2008), penutupan dan tipe vegetasi tumbuhan bawah), atau keduanya (Huang et al., 2011; Kasel et al., 2011).

\section{METODE PENELITIAN}

Penelitian dilaksanakan pada bulan Mei sampai bulan Oktober 2019 di kawasanRuang Terbuka Hijau hutan kota Muhammad Sabki, Kota Jambi. Penelitian dilakukan pada tiga zona 
pemanfaatan lahan; zona pemanfaatan rendah (01 ${ }^{\circ} 39^{\prime} 12,482^{\prime}$ LS, $103^{\circ} 34^{\prime} 56,576^{\prime}$ BT),zona pemanfaatan sedang $\left(01^{\circ} 39^{\prime} 15,068^{\prime \prime} \mathrm{LS}, 103^{\circ} 34^{\prime} 57,263^{\prime \prime} \mathrm{BT}\right)$ dan zona pemanfaatanintensif (01'39'18,977' LS, 10335'06,491').

\section{Metode Penelitian, Jenis dan Sumber Data}

Penelitian dilaksanakan dengan metode Survey. Lokasi penempatan plot ditetapkan denganmetode Purposive Sampling with Random Start. Metode ini merupakan metodepenentuan lokasi penelitian secara sengaja yang dianggap representative, sedangkanmetode pengambilan sampelnya dengan menggunakan metode kuadrat.

Pengambilan data vegetasi dan Biomassa pada masing-masing lokasi dibuat plot berukuran 20 x 20 msebanyak 3 plot untuk pohon dan 10x10 m untuk tiang. Pada setiap plot dilakukan pengamatanpada seluruh pohon yang berdiameter $>20 \mathrm{~cm}$ dengan mengukur DBH diameter batangsetinggi dada ( $1,3 \mathrm{~m}$ ), dan tiang mulai dari tegakan yang berdiameter 10-20 cm (Muller et al., 1974, dan Greig et al., 1983). Data yang diambil meliputi diameter setinggi dada pohon dan tiang.Biomassa diataspermukaan tanah dianalisis dengan menggunakan dua persamaan allometriknon detructive.

\section{$\underline{\text { Estimasi biomassa }}$}

$\operatorname{ABD}(\mathrm{kg} / \mathrm{plot})=\exp (-2,289+2,649 \times \ln \mathrm{dbh})-(0,021 \times \ln \mathrm{dbh} 2)$

$\operatorname{BBD}(\mathrm{kg} / \mathrm{plot})=\exp (-1,0587 \times(\ln \mathrm{ABD}))$

Keterangan:

$\mathrm{ABD}=$ biomassa tegakan pohon

$\mathrm{BBD}=$ biomassa akar pohon

$d b h=$ diameter pohon setinggi dada

\section{Estimasi Karbon Tersimpan(Karbon Stok)}

Estimasi karbon tersimpan masing-masing komponen denganpersamaan yang dikembangkan oleh Alternative to Slash and Burn (Hairiah dan Rahayu, 2007) :

\section{Stok $\mathbf{C}=$ Biomassa $\mathrm{x} \% \mathbf{C}$ organik}

Keterangan : Biomassa :Biomassa total masing-masing komponen

$$
\% \mathrm{C} \text { : Konsentrasi } \mathrm{C} \text { dalam bahan organik yang terdapat }
$$
pada masing-masing komponen $=0,47$

\section{$\underline{\text { Estimasi Serapan } \mathrm{CO2}}$}

Serapan CO2 adalah kemampuan tanaman dalam menyerap CO2 dalam satu luasan area. Dari hasil perhitungan karbon tersimpan di atas permukaan tanah dapat diketahui jumlah penyerapan karbon dioksida (CO2) oleh tanaman menggunakan rumus sebagai berikut 
Keterangan : Mr CO2 : Bobot molekul senyawa (44)n

Ar C : Bobot molekul atom C (12)

\section{Pelaksanaan Penelitian}

Pelaksanaan penelitian dilakukan dalam beberapa tahap yang terdiri dari tahap persiapan, tahap survei pendahuluan, tahap survei lapangan (survei utama) dan tahapan pasca survei lapangan. Pelaksanaan survei pendahuluan meliputi pengurusan izin untuk lokasi penelitian pada hutan kota Muhamad Sabki, Grouncheck lokasi untuk memeriksa kesesuaian antara rencana penelitian dengan kondisi di lapangan, melakukan kunjungan ke daerah penelitian untuk mendapatkan gambaran umum dan kondisi lahan. Berdasarkan survei pendahuluan akan ditetapkan lokasi pengamatan intensif, titik pengambilan contoh tanaman dan contoh tanah untuk pengukuran biomasa.

\section{Survei Utama}

Survei utama mencakup kegiatan pengukuran langsung dilapangan, diawali dengan memasukkan plot pengamatan yang telah dibuat pada proposal penelitian ke dalam GPS dengan sistem koordinat Decimal Degree. Kemudian menggunakan fungsi GO TO pada GPS untuk menuju ke titik pengamatan sesuai dengan peta kerja. Setelah itu dilakukan pengumpulan data - data primer yang dibutuhkan, sebagai berikut :

\section{Pengamatan Contoh Tanah}

Pengambilan sampel tanah dilakukan pada setiap jenis vegetasi sesuai pemanfaatan lahan yang berbeda. Analisis sampel tanah di laboratorium meliputi analisis contoh tanah terganggu untuk menentukan tekstur tanah sedangkan tanah tak terganggu untuk menentukan bobot isi tanah, total ruang pori dan kadar air tanah.

\section{HASIL DAN PEMBAHASAN}

\section{Bahan Organik dan Sifat Fisik Tanah Hutan Kota}

Kandungan bahan organik pada tingkat pemanfaatan rendah relatif lebih tinggi dibandingkan pemanfaatan sedang maupun intensif (Tabel 1). Hal ini menunjukkan pada pemanfaatan rendah terjadi banyak sumbangan bahan organik melalui serasah tumbuhan, diikuti pemanfaatan sedang dan intensif. Sesuai dengan Berg et al., (2009); Vesterdal et al., (2008) bahwa produksi dan kualitas serasah yang dipengaruhi oleh jenis pohon mempunyai pengaruh yang kuat terhadap dinamika SOC. Pemanfaatan lahan intensif diduga tidak mendapatkan serasah yang banyak karena lahan lebih banyak dimanfaatkan untuk area rekreasi dan secara umum tidak terlihat serasah yang terpapar dipermukaan tanah. 
Tabel 1. Bahan organik, bobot volume dan total ruang pori tanah Hutan Kota M Sabki

\begin{tabular}{lllll}
\hline Pemanfaatan & Tapak & BO \%) & BV $\left(\mathrm{g} / \mathrm{cm}^{3}\right)$ & TRP $(\%)$ \\
\hline Rendah & Rataan & 7.28 & 1.09 & 59.81 \\
Sedang & Rataan & 6.40 & 1.12 & 58.55 \\
Intensif & Rataan & 5.05 & 1.12 & 55.78 \\
\hline
\end{tabular}

Bobot volume tanah lahan pemanfaatan rendah lebih kecil dibandingkan pemanfaatan sedang dan intensif. namunpemanfaatan sedang maupun intensif memliki BV relatif sama. NilaiBV tanah hutan kota M Sabki antara 1,09-1,12 $\mathrm{g} / \mathrm{cm}^{3}$. Zona pemanfaatan rendah memiliki kepadatan rendah, hal ini dimungkinkan karena aktifitas manusia pada wilayah tersebut lebih sedikit sehingga proses pemadatan dari permukaan ta nah lebih rendah.

Porositas tanah Hutan Kota M Sabki menunjukkan nilai rata rata yang relatif rendah, $59,81 \%$ pada wilayah pemanfaatan rendah, diuti berurutan pemanfaatan sedang dan intensif $57,55 \%$ dan 55,78\% (Tabel 1). Hal ini dimungkinkan karena prositas tanah ditentukan oleh kepadatan tanah dan kandungan bahan organic. Kandungan bahan organik tinggi dan kepadatan rendah menyebabkan porositas tanah tinggi.

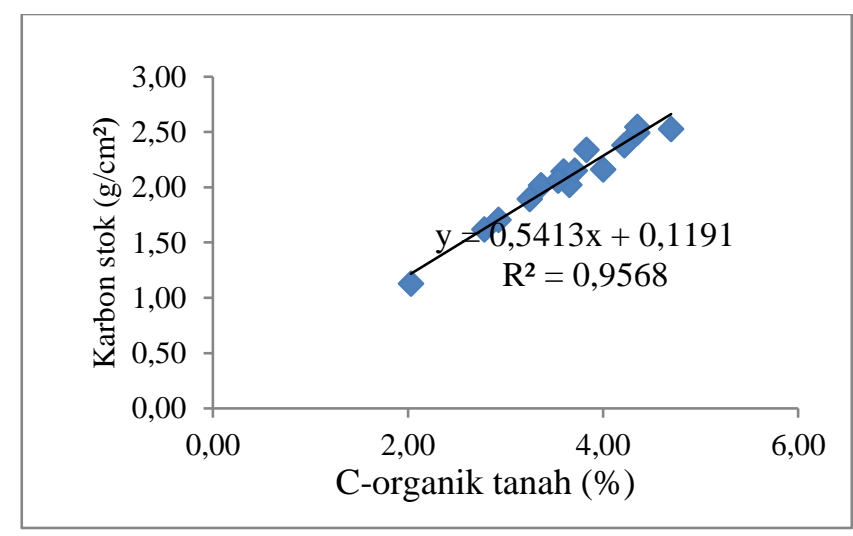

Gambar 1. Kurva hubungan C-organik tanah dengan stok karbon

Hal ini diduga karena porositas tanah tidak hanya dipengaruhi kandungan bahan organik tanah, namun juga dipengaruhi parameter yang lain. Kandungan C-organik tanah menentukan jumlah karbon stok atau simpanan karbon dalam tanah, semakin besar kandungan C-organik tanah akan semakin besar cadangan karbon dalam tanah. Gambar 1 menunjukkan bahwa Corganik sangat menentukan karbon stok dalam tanah. 


\section{Biomassa, Stok Karbon dan Sekuestrasi Karbon Vegetasi pada Hutan Kota M Sabki}

Hasil survei dan identifikasi vegetasi pohon hingga tiang disajikan pada Tabel 5.Hutan Kota M Sabki memiliki vegetasi berdiameter $>10 \mathrm{~cm}$ didominasi vegetasi Medang medangan yang berummur di atas 50 tahun, diikuti vegetasi tembesi, kulit manis, gaharu, durian, , jengkol, karet, mahoni, rambutan,nibung dan lainnya. Hal ini menunjukkan bahwa hutan kota M Sabki memiliki system ekologis yang sudah menyerupai hutan. Keberadaan vegetasi karet, rambutan dan kulit manis menunjukkan bahwa hutan kota sudah mengalami suksesi menyerupai hutan sekunder.

Berbagai jenis vegetasi dijumpai di Hutan kota ini, beberapa di antaranya memiliki kerapatan yang tinggi, sementara itu vegetasi yang dijumpai umumnya adalah vegetasi serupa dengan tmbuhan hutan. Vegetasi jenis Medang-medangan dijumpai paling banyak (36 individu), kemudian kulit manis (18 individu), tembesu ( 7 individu), karet ( 7 individu), rambutan, mahoni, durian dan lainnya. Keberadaan vegetasi tersebut mengindikasikan bahwa hutan kota M Sabki merupakan suksesi hutan sekunder.

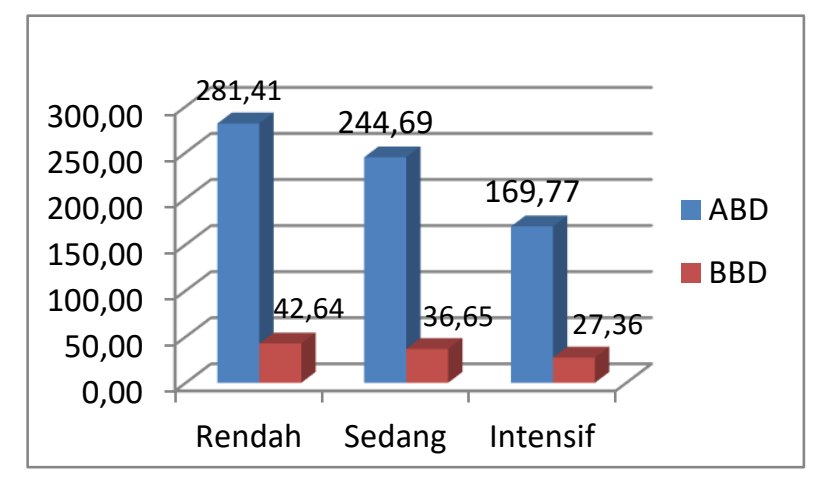

Gambar 1. Grafik Biomassa Tegakan Pohon Atas dan Bawah Permukaan

Biomassa yang tinggi dimungkinkan karena kerapatan vegetasi yang tinggi, juga karena dijumpai beberapavegetasi dengan diameteryang besar dan umur yang sudah tua Gambar 1).Biomassa tegakan pohon di atas permukaan berkontribusi sebesar $86,84 \%$ dan biomassa bawah permukaan berkontribusi sebebesar 13,16 \%. Biomassa pada area pemanfaatan sedang berkontribusi sebesar 86,97 \% dan biomassa bawah permukaan berkontribusi sebesar $13,03 \%$. Biomassa pada area pemanfaatan intensif atas permukaan berkontribusi sebesar 86,12 \% sedangkan biomasaa bawah permukaan berkontribusi sebesar $13,88 \%$.

Perbedaan nilai biomassa pada tiap jenis tanaman ditentukan oleh diameter tanaman dan berat jenis tanaman. Menurut Danarto dan Setyorini (2019) biomassa tanaman merupakan ukuran yang sering menggambarkankan pertumbuhan tanaman yang menyatakan berat bahan hidup yang dihasilkan oleh tanaman. Potensi biomassa dipengaruhi oleh umur pohon yang merupakan diameter adalah fungsi dari umur pohon. Sato et al. (2014) menyatakan 
kandungan karbon di pohon memiliki hubungan yang signifikan dengan diameter pohon. Total jumlah karbon dalam plot dinyatakan sebagai jumlah nilai karbon yang diduga oleh diameter yang dimasuk ke dalam persamaan.

Mengukur jumlah karbon yang tersimpan dalam tubuh tanaman (biomassa) pada suatu areal akan menggambarkan banyaknya $\mathrm{CO} 2$ yang diserap tanaman di atmosfer (Ratnaningsih dan Suhesti, 2010).

Tabel 6. Nilai rata rata biomassa, Stok karbon, sink CO2 dan Produksi O2

\begin{tabular}{lllll}
\hline Pemanfaatan & $\begin{array}{l}\text { Biomassa } \\
\text { (ton/ha) }\end{array}$ & $\begin{array}{l}\text { Stok C } \\
\text { (ton/ha) }\end{array}$ & $\begin{array}{c}\text { Sink CO2 } \\
\text { (ton/ha) }\end{array}$ & $\begin{array}{c}\text { Prods O2 } \\
\text { (ton/ha) }\end{array}$ \\
\hline Rendah & 350.60 & 164.78 & 604.20 & 441.06 \\
Sedang & 305.72 & 143.69 & 526.86 & 384.61 \\
Intensif & 225.66 & 106.06 & 389.24 & 284.15 \\
\hline
\end{tabular}

\section{Stok Karbon}

Pohon menyediakan jasa ekosistem penting, salah satu diantaranya adalah sebagai penyimpan karbon. Ruang terbuka hijau (RTH) didefinisikan sebagai kumpulan dari semua tumbuhan berkayu dan asosiasi vegetasi di dalam dan sekitar pemukiman padat penduduk (Andriono et al., 2013). Hutan Kota M Sabki sebagai RTH di kota Jambi diharapkan dapat mengurangi emisi CO2 dan menjadi paru paru kota.

Hasil penelitian menunjukkan stok karbon hutan kota pemanfaatan rendah 132,26 ton/ha, pemanfaaran sedang 115 ton/ha, serta pemanfaatan intensif 125,22 ton.ha. Stok karbon yang tinggi pada wilayah pemanfaatan rendah terjadi karena biomassa vegetasi yang juga tinggi, diikuti pemnfataan intensif dan sedang. Dinamika stok karbon pada vegetasi bagian atas diikuti data stok karbon bawah permukaan 10,36 ton/ha (pemanfaatan rendah), 9,51 ton/ha (pemanfaatan sedang) dan 11,18 ton.ha (pemanfaatan intensif).

Hutan Kota dapat mengurangi tingkat gas $\mathrm{CO} 2$ melalui penyerapan dan mengurangi emisi CO2 lewat konservasi energi yang digunakan untuk pemanasan dan pendinginan. Pohon dan semak mampu mengubah $\mathrm{CO} 2$ menjadi biomassa di atas permukaan dan bawah tanah. melalui fotosintesis, sebuah proses yang dinamakan penyerapan karbon, dan penyimpanan karbon dalam bentuk batang, ranting, atau akar (Nowak dan Crane dalam Liu dan Li, 2012).

Hasil penelitian inimenunjukkan bahwa hutan Kota M Sabki sudah menyerupai hutan lahan kering sekunder, sesuai dengan laporan Balitbang Kehutanan (2014) bahwa hutan lahan kering memiliki stok karbon minimal 71,48 dan maksimal 216,85 ton/ha. 
Sesuai dengan pernyataan Adinugroho (2011) yatakan bahwa rata-rata cadangan karbon tidak hanya dipengaruhi oleh satu parameter saja, tetapi juga dipengaruhi oleh diameter tanaman, keanekaragaman jenis tanaman, kerapatan individu yang secara bersamasama parameter tersebut memberikan kontribusi dalam besarnya nilai cadangan karbon suatu tegakan. Semakin besar diameter pohon yang didukung dengan jumlah yang banyak maka potensi cadangan karbonnya juga akan semakin besar. Selain hal tersebut menurut pernyataan Combalicer (2011) bahwa tingginya nilai potensi simpanan karbon lebih dipengaruhi oleh faktor diameter dan berat jenis vegetasinya.

Menurut Hairiah dan Rahayu (2007), jumlah C tersimpan antar lahan berbeda-beda, tergantung pada keragaman dan kerapatan tumbuhan yang ada, jenis tanahnya serta cara pengelolaannya. Diperkuat Chairul (2016) bahwa variasi tersebut juga dipengaruhi oleh tipe hutan, jenis vegetasi, tipe iklim dan curah hujan, topografi, dan kondisi biofisik lainnya, termasuk teknik silvikultur dan manajemen hutan yang diterapkan.Prosentase kandungan karbon dalam bahanorganik adalah $47 \%$ dari jumlah biomassanya (Hairiyah dan Rahayu, 2007)

Pemanfaatan kawasan rendah mampu mensekuestrasi CO2 604,20 ton/ha, kawasan sedang mensekuestrasi CO2 526,86 ton/ha, dan 566,62 ton/ha pada kawasan pemanfaatan intensif.Diduga jumlah serapan karbon ini dipengaruhi oleh kondisi iklim, topogafi jenis vegetasi dan kerapatan vegetasinya. Tingkat keterserapan karbon yang besar pada umumnya terjadi pada kawasan hutan dengan tingkat kesuburan yang tinggi dan curah hujan cukup, dan pada tanaman yang cepat tumbuh.

Serapan $\mathrm{CO} 2$ oleh tegakan berbagai vegetasi menggambarkan kemampuan vegetasi yang berada di luar kawasan hutan ini untuk memfiksasi CO2 yang kemudian disimpan dalam bentuk cadangan karbon pada tegakan pohon tersebut. Tegakan vegetasi hutan Kota M Sabki yang ditanam sebagai tanaman penghijauan kota mempunyai kemampuan menyerap karbon dengan jumlah yang cukup besar. Di samping itu, tanaman ini mempunyai sistem perakaran tunggang yang kuat dan tahan terhadap gangguan fisik..

Melalui proses fotosintesis, CO2 di udara diserap oleh tanaman dan dengan bantuan sinar matahari kemudian diubah menjadi karbohidrat untuk selanjutnya didistribusikan keseluruh tubuh tanaman dan ditimbun dalam bentuk daun, batang, cabang, buah, dan bunga (Hairiah dan Rahayu 2007). Tegakan atau pohon berumur panjang seperti Medang, pulai dll yang tumbuh di hutan maupun di kebun campuran merupakan tempat penimbunan atau penyimpanan $\mathrm{C}$ yang jauh lebih besar dari pada tanaman semusim karena pada tanaman tahunan seperti di tegakan medang di lokasi Hutan Kota M Sabki ini memiliki siklus hidup yang lebih panjang sedangkan pada tanaman semusim lepasnya karbon akan lebih cepat mengingat setelah tanaman tidak berproduksi akan di ganti dengan tanaman yang baru.

Hasil penelitian menunjukan bahwa keberadaan tegakan vegetasi dalam kawasan hutan Kota M Sabki memproduksi oksigen mencapai 441,06 pada kawasan pemanfaatan 
rendah, 384,61 ton/ha pada kawasan sedang, dan 413,85 pada kawasan intensif Keberadaan Taman Hutan Kota di kawasan perkotaan sangat penting dalam mendukung keberlangsungan sebuah kota ditinjau dari segi ekologis. Fungsi intrinsik (utama) RTH beragam, diantaranya yaitu sebagai produsen (penghasil) oksigen. Oksigen merupakan kebutuhan dasar yang mutlak diperlukan oleh sebuah kota baik oleh penduduk, kendaraan bermotor, hewan ternak, maupun industri. Gas oksigen merupakan gas yang dibutuhkan oleh makhluk hidup untuk proses respirasi.

Luas RTH berbanding lurus dengan besar/kecilnya produksi O 2 , yaitu semakin tinggi luas RTH akan semakin besar jumlah O 2 yang dihasilkan dan semakin rendah luas RTH akan semakin sedikit jumlah O 2 yang dihasilkan. Pengalihfungsian ruang terbuka hijau menjadi kawasan terbangun di Kota Jambi pada akhirnya menyebabkan penurunan produksi oksigen.

Konsumsi oksigen penduduk adalah sebesar $0,864 \mathrm{~kg} / \mathrm{jiwa} / \mathrm{hari}$. Dengan jumlah penduduk sebanyak 610.854 jiwa (Kota Jambi Dalam Angka, 2018), maka konsumsi oksigen Kota Jambi adalah 527.78ton O 2 /hari. Jika luas terbuka hijau (RTH) Hutan Kota M Sabki adalah 11 ha (maka produksi O 2 yang mampu dihasilkan (Gerakis dalam Wisesa, 1988) oleh RTH adalah sebesar 1935.185 ton O2/hari sehingga Kota Jambi memerlukan adanya penambahan ruang terbuka hijau (RTH). Hutan kota sebagai unsur RTH merupakan sub sistem kota, sebuah ekosistem dengan sistem terbuka. Pemerintah Kota Jambi melalui dinas Lingkungan Hidup masih berupaya menyediakan minimal dua unit hutan kota di masingmasing kecamatan. Konsistensi pengembangan hutan kota diharapkan dapat menjadi gambaran upaya optimasi yang dapat dilakukan dalam meningkatkan produksi oksigen yang mampu dihasilkan oleh RTH khususnya hutan kota M Sabki di Kota Jambi.. Penelitian ini diharapkan dapat memberikan kontribusi terhadap peningkatan kesadaran pemerintah dan masyarakat terhadap usaha pelestarian hutan kota, sehingga tercipta hubungan yang saling menguntungkan dan berkelanjutan. Pengukuran produksi oksigen pada penelitian ini relevan dengan pengukuran biomassa. Biomassa hutan kota menyediakan informasi penting dalam menduga besarnya potensi oksigen yang mampu dihasilkan.

\section{KESIMPULAN DAN SARAN}

\section{Kesimpulan}

Hutan Kota M Sabki memiliki sifat fisik tanah bervariasi menurut areapemanfaatan lahan, di antaranya terdapat variasi terhadap kadar air, bobot tanah kering, bobottanah basah, bobot volume tanah, porositas tanah. Fungsi hidrologis lahan hutan kota M Sabki secara keseluruhan berfungsi dengan baik, dengan indikasi kemampuan melewatkan dan menyimpan air yang baik, akibat sifat fisik yang baik dan bahan organic yang relatif sedang. Area pemanfaatan rendah memiliki kerapatan pohon lebih tinggi dibandingkan zona pemanfaatan sedang dan pemanfaatan intensif. 
Hutan kota M Sabki pada area pemanfaatan rendah memiliki biomassa atas permukaan sebesar350,60 ton/ha, stok karbon 164,78 ton/ha, sekuestrasi CO2 sebesar 604,20 ton/ha dan mampu memproduksi $\mathrm{O} 2$ sebesar 441,06 ton/ha. Biomassa pada area pemanfaatan sedang sebesar 305,72 ton/ha, stok karbon sebesar 143,69, sekuestrasi CO2 sebesar 526,86, serta mampu memproduksi $\mathrm{O} 2$ sebesar 384,561 ton/ha. Biomasapada area pemanfaatan intensif sebesar 225,66 ton/ha, stok karbon sebesar 106,06, sekuestrasi CO2 sebesar 389.24, serta mampu memproduksi O2 sebesar 284,15 ton/ha.

\section{Saran}

Hasil penelitian ini menggambarkan bahwa hutan kota M Sabki memiliki vegetasi dengan biomassa menyerupai hutan sekunder, mampu menyerap karbon dan memproduksi oksigen. Masukan kepada pemerintah dan stake holder terkait bahwa sangat penting mempertahankan dan mengembangkan RTH seperti hutan kota M Sabki dengan tegakan vegetasi tumbuhan hutan berkayu seperti medang medangan, mempertahankan vegetasi dengan $\mathrm{DBH}>20 \mathrm{~cm}$.

\section{UCAPAN TERIMA KASIH}

Penelitian ini di danai oleh Dana Dipa PNBP Universitas Jambi tahun 2019, terima Kasih kepada Bapak rector Un iversitas Jambi yang telah menyetujui, kepada ketua LP2P Universitas Jambi dan Dekan Fakultas Pertanian Universotas Jambi yang telah memfasilitasi sehingga penelitian ini bisa terlaksana.

\section{Daftar Pustaka}

Adinugroho, W.C. 2010. Pendugaan Cadangan Karbon dalam Rangka Pemanfaatan Fungsi Hutan Sebagai Penyerap Karbon. Hutan dan Konservasi AlamVol III No. 1: 103-117

Andriono ,F., I. Hanafi, B. Yanuwiadi, Soemarno,.2013. Green Open Space Scenarios

in Reducing CO2 Emissions in Malang City. Indonesia: A Dynamic System Approach,The International Journal of Engineering And Science, Vol 3 Issue 6, 6-8.

Badan Pusat Statistik Propinsi Jambi Dan Badan Perencanaan Pembangunan Daerah(BAPPEDA) Propinsi Jambi.2018. Jambi Dalam Angka 2018. Jambi.

Berg, B., Johansson, M.B., Nilsson, A., Gundersen, P., \& Norell, L. (2009).

Sequestration of carbon in the humus layer of Swedish forests-direct measurements. Can. J. For. Res. 39, 962-975

Brown S, Lugo AE. 1990. Tropical secondary forests. J Trop Ecol. 6: 1-32. 
Brown dan Sandra. 1997. Estimating Biomass and Biomass Change of Tropical Forests: a Primer. (FAO Forestry Paper - 134). FAO.Rome

Chairul., Muchktar, E., Mansyurdin., Tesri, M dan Indra, G. 2016. Struktur Kerapatan

Vegetasi dan Estimasi Kandungan Karbon pada beberapa Kondisi Hutan di Pulau Siberut Sumatera Barat. Jurnal Metaforsa 3(1): 15-22.

Chrysanthou, A., Schrier, G., Besselaar, E. J. M., Klein Tank, A. M. G., and Brandsma, T. (2014). The effects of urbanization on the rise of the European temperature since 1960. Geophys. Res. Lett. 41, 7716-7722. doi: 10.1002/2014GL.061154

Combalicer, M.S., D. K. Lee, S. Y. Woo, P. S. Park, K. W. Lee, E. L. Tolentino, E. A. Combalicer, Y. K. Lee and Y. D. Park. 2011. Aboveground Biomass and Productivity of Nitrogen-Fixing Tree Species in The Philippines. Scientific Research and Essays

Danarto SA dan T Setyorini ( 2019) .Seleksi tumbuhan dataran rendah kering yang berpotensi tinggi dalam sekuestrasi karbon untuk rehabilitasi kawasan terdegradasi. Prosiding Seminar Masyarakat Biodiversitas Indonesia. Vol 5 No.1 Maret 2019

Davies, Z. G., Edmondson, J. L., Heinemeyer, A., Leake, J. R., and Gaston, K. J. (2011).

Mapping an urban ecosystem service: quantifying above-ground carbon storage at a city-wide scale. J. Appl. Ecol. 48, 1125-1134. doi: 10.1111/j.1365-2664.2011.02021.x

Gong, P., Liang, S., Carlton, E. J., Jiang, Q., Wu, J., Wang, L., et al. (2012). Urbanisation and health in China. Lancet 379, 843-852. doi: 10.1016/S0140-6736(11)61878-3

Hairiah, K dan Rahayu, S. 2007. Pengukuran Karbon Tersimpan di Berbagai Macam

Penggunaan Lahan. World Agroforestry Centre. ICRAF, SEA Regional Office, University of Brawijaya, Indonesia. Bogor. 77

Huang, Z., Davis, M.R., Condron, L.M., Clinton, P.W. (2011). Soil carbon pools, plant biomarkers and mean arbon residence time after afforestation of grassland with three tree species. Soil Biol. Biochem. 43, 1341-1349.

Hutyra, L. R., Yoon, B., and Alberti, M. (2011). Terrestrial carbon stocks across a gradient of urbanization: a study of the Seattle, WA region. Glob. Chang. Biol. 17, 783-797. doi: 10.1111/j.1365-2486.2010.02238.x

Kasel, S., Singh, S., Sanders, G.J., \& Bennett, L.T. (2011). Species specific effects of native trees on soil organic carbon in biodiverse plantings across north-central Victoria, Australia. Geoderma 161, 95-106. 
Kementerian Lingkungan Hidup. 2010. Laju kerusakan hutan masih tinggi upaya pemulihan belum seimbang. http://www.menlh.go.id. [30 Juni 2010].

McHale, M. R., Baker, L. A., Koerner, B. A., Li, K., Hall, S. J., and Grimm, N. B. (2009). "Impacts of urbanization on carbon cycling: a complete carbon budget of the Phoenix metropolitan area," Ecological Society of America Annual Meeting (Albuquerque, NM).

Nowak, D. J., Hirabayashi, S., Bodine, A., and Greenfield, E. (2014). Tree and forest effects on air quality and human health in the United States. Environ. Pollut. 193, 119-129. doi: 10.1016/j.envpol.2014.05.028

Nowak, D. J., Hirabayashi, S., Bodine, A., and Hoehn, R. (2013). Modeled PM 2.5 removal by trees in ten US cities and associated health effects. Environ. Pollut. 178, 395-402. doi: 10.1016/j.envpol.2013.03.050

Raciti, S. M., Hutyra, L. R., and Newell, J. D. (2014). Mapping carbon storage in urban trees with multisource remote sensing data: Relationships between biomass, land use, and demographics in Boston neighborhoods. Sci. Total Environ. 500, 72-83. doi: 10.1016/j.scitotenv.2014.08.070

Ratnaningsih, A.T. dan E. Suhesti. 2010. Peran Hutan Kota dalam Meningkatkan Kualitas Lingkungan. Journal of Environmental Science 2010:1(4).

Seto, K. C., Güneralp, B., and Hutyra, L. R. (2012). Global forecasts of urban expansion to 2030 and direct impacts on biodiversity and carbon pools. Proc. Natl. Acad. Sci. U.S.A. 109, 16083-16088. doi: 10.1073/pnas.1211658109

Seto, K. C., Dhakal, S., Bigio, A., Blanco, H., Delgado, G. C., Dewar, D., et al. (2014). Human Settlements, Infrastructure and Spatial Planning. Intergovernmental Panel on Climate Change. Working Group III- Mitigation of Climate Change. Cambridge; New York, NY: Cambridge University Press.

United Nations (UN) (2015). World Urbanization Prospects: The 2014 Revision. New York, NY: United Nations Department of Economic and Social Affairs, Population Division

Vesterdal, L., Schmidt, I.K., Callesen, I., Nilsson, L.O., \& Gundersen, P. (2008). Carbon and nitrogen in forest floor and mineral soil under six common European tree species. For. Ecol. Manag. 255, 35-48.

Young, G. S., Fox, M. A., Trush, M., Kanarek, N., Glass, T. A., and Curriero, F. C. (2012). Differential exposure to hazardous air pollution in the United States: a multilevel analysis of urbanization and neighborhood socioeconomic deprivation. Int. J. Environ. Res. Public Health 9, 2204-2225. doi: 10.3390/ijerph9062204 
Zhou, D. C., Zhao, S. Q., Liu, S., Zhang, L., and Zhu, C. (2014). Surface urban heat island in China's 32 major cities: spatial patterns and drivers. Remote Sens. Environ. 152, 51-61. doi: 10.1016/j.rse.2014.05.017 